\title{
Novosti u dijagnostici malignog mezotelioma pleure
}

\section{Advances in the diagnosis of malignant pleural mesothelioma}

\author{
Martina Murkovići ${ }^{*}$, Ana Benvin², Christophe Štemberger ${ }^{1}$, Danijela Vrdoljak-Mozetič ${ }^{1}$
}

${ }^{1}$ Klinički zavod za patologiju i citologiju, Klinički bolnički centar Rijeka, Rijeka, Hrvatska

${ }^{2}$ Sveučilište u Rijeci, Medicinski fakultet, Rijeka, Hrvatska

\section{"Dopisni autor:}

Martina Murković, dr. med. Klinički bolnički centar Rijeka Krešimirova 42, 51000 Rijeka, Hrvatska E-mail:mmurkovic75@gmail.com
Sažetak. Maligni mezoteliom (MM) pleure agresivna je maligna bolest čija je incidencija u porastu. Dijagnostika MM-a izazovna je zbog kasnog javljanja simptoma bolesti, a problem predstavljaju poteškoće razlikovanja benignih i malignih lezija što ponekad odgađa dijagnozu. Slikovna procjena najčešće se provodi CT (engl. Computed tomography) dijagnostikom, dok se konačna dijagnoza uspostavlja nakon biopsije i analize patohistološkog uzorka. Dijagnozu epiteloidnog mezotelioma moguće je uspostaviti citološkom analizom pleuralnog izljeva, gdje su potrebna dva pozitivna imunocitokemijska markera koji potvrđuju dijagnozu te dva negativna markera koji isključuju dijagnozu. Cilj je ovog rada prikazati trenutna saznanja o slikovnim, citološkim i patohistološkim metodama dijagnosticiranja MM-a.

Ključne riječi: citologija; imunohistokemija; maligni mezoteliom; slikovna dijagnostika

Abstract. Malignant pleural mesothelioma (MPM) is an agressive neoplasm with an increasing incidence rate. MPM has a delayed onset of symptoms, and diagnosis is often challenging because of the difficulties in the differentiation of the benign and malignant lesions. СT (Computed tomography) is used for imaging assessment of mesothelioma, while biopsy and histopathology give the definitive confirmation of the MPM. Cytology analyis of the pleural effusion with two immunocytochemistry markers in favor of MPM and two excluding the diagnosis are sufficient to diagnose MPM. The aim of this review is to summarize recent diagnostic methods in MPM diagnosis.

Key words: cytology; imaging; immunohistochemistry; malignant mesothelioma

http://hrcak.srce.hr/medicina 


\section{UVOD}

Maligni mezoteliom (MM) agresivni je tumor pleure te rjeđe peritoneuma, perikarda i tunike vaginalis testisa. Glavni faktor rizika malignog mezotelioma pleure (MMP) prethodna je ekspozicija azbestu, a povezanost je potvrdio Wagner 1960. godine istražujući nagli porast incidencije mezotelioma u industrijskih radnika u Južnoj Afri$\mathrm{ci}^{1}$. Karakteristični su dugi periodi latencije od ekspozicije do pojave bolesti koji prosječno traju oko 40 godina, iako su u nekim slučajevima zabilježeni periodi latencije od 50 do 60 godina.

Stope preživljavanja oboljelih od malignog mezotelioma vrlo su niske, a medijan preživljavanja je između 9 i 12 mjeseci². Incidencija malignog mezotelioma pleure je u porastu, u svijetu ona iznosi 2-3 slučaja na 100000 stanovnika godišnje, dok je u Republici Hrvatskoj stopa incidencije 1,8 slučaja na 100000 stanovnika za 2015. godinu³ ${ }^{3}$.

Dijagnostika malignog mezotelioma pleure započinje nakon javljanja simptoma bolesti radiogramom prsnog koša i CT dijagnostikom. Slikovna dijagnostika ne može potvrditi bolest, stoga je potrebno napraviti pleuralnu punkciju kako bi se dobio citološki uzorak ili biopsiju kojom se dobiva histološki uzorak. Problem predstavlja kasno javljanje simptoma bolesti, a potvrdu dijagnoze mogu odgoditi poteškoće razlikovanja malignih i benignih lezija te nedovoljna senzitivnost i specifičnost dijagnostičkih metoda ${ }^{4}$. Cilj je ovog rada prikazati trenutne dijagnostičke postupke u procjeni malignog mezotelioma pleure.

\section{SLIKOVNA DIJAGNOSTIKA}

Slikovna je dijagnostika važna u inicijalnoj procjeni kod sumnje na MMP te se koristi i kod određivanja stadija tumora ${ }^{5}$. Većina pacijenata na početku bolesti ima unilateralni plućni izljev na radiogramu prsnog koša, a osim pojave izljeva čest je gubitak hemitorakalnog volumena, nalaz nodularnih zadebljanja pleure, nepravilnih zadebljanja fisura te nalaz lokaliziranih tumorskih masa ${ }^{5}$. Bilateralni pleuralni izljev snažan je indikator da se ne radi o malignom mezoteliomu te upućuje na metastatsku bolest ${ }^{6}$. Prisutnost pleuralnih plakova može pobuditi sumnju na prethodnu izloženost azbestu ${ }^{5}$. Radiološki nalaz nije dovoljno senzitivan i specifičan, ali preporučuje se kao pretraga prve linije zbog relativno male doze ionizirajućeg zračenja i dostupnosti te vodi do daljnje dijagnostike kako bi se identificirala ili isključila maligna bolest ${ }^{5,7}$. Uz radiogram prsnog koša, dijagnostička metoda koja se često primjenjuje kod inicijalne pojave simptoma jest torakalni ultrazvuk. Torakalnim ultrazvukom moguće je vizualizirati pleuralni izljev, zadebljanja pleure te tumor ili nodularne lezije na pleuri ili hemidijafragmi $^{5}$. Ultrazvučni nalaz koji upućuje na malignitet

Maligni mezoteliom pleure agresivna je bolest koja se otkriva u uznapredovalom stadiju kada su terapijske mogućnosti ograničene. Rana detekcija mezotelioma povezana je $s$ boljim preživljavanjem pacijenata, stoga je vrlo važan razvoj novih i manje invazivnih dijagnostičkih metoda koje će omogućiti otkrivanje bolesti u ranijem stadiju.

uključuje pronalazak pleuralne mase ili pleuralnog zadebljanja $>1 \mathrm{~cm}$, nodularnih pleuralnih zadebljanja te nodularnih lezija dijafragme ${ }^{5}$. Ovakav je ultrazvučni nalaz 95 \% specifičan za maligne lezije te $40 \%$ senzitivan $^{5}$. lako nije prikladan za izravnu dijagnozu malignog mezotelioma, važan je alat pri pleuralnoj punkciji ili perkutanoj biopsiji pleuralne mase ${ }^{7}$. СT (engl. Computed tomography) dijagnostika najčešće se primjenjuje za početnu procjenu bolesti te za procjenu odgovora na terapiju ${ }^{8}$. CT je ključan u dijagnostici mezotelioma, ali ujedno i zahtjevan zbog poteškoće razlikovanja malignih lezija od benignog zadebljanja pleure ${ }^{8,9}$. Karakteristike koje upućuju na malignu bolest jesu kružno zadebljanje pleure, parijetalno zadebljanje $>1 \mathrm{~cm}$, nodularna parijetalna zadebljanja i medijastinalne promjene $e^{4,8,9}$. Znak podijeljene pleure, gdje su visceralna i parijetalna pleura zadebljane i jačeg intenziteta s pleuralnim izljevom između, te pojačana gustoća ekstrapleuralnog masnog tkiva zbog subpleuralnog edema znakovi su koji ukazuju na benignu bolest $^{7}$. Prema Bibby i suradnicima CT dijagnostika ima senzitivnost i specifičnost od $68 \%$ odnosno $78 \%$ kod dijagnostike pleuralnih malignih lezija $^{5}$. CT ne može sa sigurnošću razlikovati maligni mezoteliom od metastatskih lezija pleure ${ }^{6}$. 
Kod PET/CT (engl. Positron emission tomography/ Computed tomography) dijagnostike akumulacija FDG (Flor-deoksiglukoza) viša je kod malignih lezija u odnosu na benigne lezije, no ne može razlikovati maligni mezoteliom od metastatskih lezija 5 . FDG je marker metaboličke aktivnosti tumora te postoji mogućnost lažno negativnog nalaza ako se dijagnostika primijeni u ranijim stadijima bolesti ili ako tumor ima nisku metaboličku aktivnost ${ }^{5}$. Lažno pozitivan nalaz moguć je kod upalnih procesa kao što su reumatoidni pleuritis te tuberkulozni pleuritis te kod pacijenata koji su prethodno bili podvrgnuti talk-pleurodezi $i^{5,7}$. Senzitivnost $i$ specifičnost PET/CT-a u dijagnostici malignog mezotelioma nije dovoljno visoka da bi se ova pretraga uključila u rutinsku dijagnostiku mezotelioma, ali moguća je primjena u određivanju stadija bolesti pošto je ova dijagnostika osjetljivija pri nalazu nodalnih lezija te ekstratorakalnih metastaza u odnosu na $\mathrm{CT}^{5}$. MR (magnetska rezonancija) i PET/CT koriste se kad je potrebna detaljna informacija kod pacijenata kod kojih se razmatra operativni zahvat jer bolje definiraju anatomske površine, vaskularizaciju i metaboličku aktivnost tumora te je moguće detektirati metastatske drenirajuće limfne čvorove i udaljene metastaze $^{8}$. MR se može primijeniti kao dijagnostička metoda i kod određivanja stadija bolesti zbog jasnijeg razlikovanja maligne i benigne bolesti te veće senzitivnosti za identificiranje lokalne invazije ${ }^{4,9}$. Kombinacije MR-a i kontrastnih agensa kao što je gadolinij te korištenje metoda kao što su DWI-MRI (engl. Diffusion-weighted magnetic resonance imaging) može podignuti senzitivnost $i$ specifičnost diferenciranja malignih i benignih lezija > $90 \%{ }^{5}$. MR se trenutno ne koristi rutinski u dijagnostici malignog mezotelioma te nema standardiziranih smjernica za primjenu MR i PET/CT dijagnostike kod malignog mezotelioma pleure ${ }^{8}$.

\section{PATOHISTOLOŠKA I CITOLOŠKA} DIJAGNOSTIKA

Za dijagnostiku malignog mezotelioma potrebno je dobiti uzorak pleuralnog izljeva i/ili bioptirati lezije pleure kako bi se dobilo tkivo za patohistološku analizu ${ }^{10}$. Neki od dijagnostičkih postupaka jesu torakocenteza, biopsija širokom iglom (engl. core needle biopsy), torakoskopska biopsija te otvorena biopsija pleure ${ }^{10}$. Prognoza bolesti poboljšava se ukoliko je dijagnoza MMP-a postavljena u što ranijoj fazi bolesti, uz posljedično raniji početak liječenja. Jedan od ranijih znakova bolesti, a ponekad i jedini, jest pleuralni izljev pa se citološka analiza pleuralnog izljeva može upotrijebiti za ranije postavljanje dijagnoze. Stoga se patohistološka dijagnostika MMP-a, koja je zlatni standard morfološke dijagnostike, može nadopuniti citološkom dijagnostikom koja prema različitoj literaturi ima senzitivnost od $13 \%$ pa do $75 \%{ }^{11,12}$. Ovako širok spektar senzitivnosti, odnosno visoke stope lažno negativnih rezultata, pripisuje se razlikama u uzorkovanju, a ne razlikama u interpretaciji uzoraka. Citološki uzorak izljeva dobiva se pleuralnom punkcijom koja je ujedno terapijski i dijagnostički postupak kod pacijenata $\mathrm{s}$ pleuralnim izljevom ${ }^{10}$. Prema literaturi, $19 \%$ pacijenata kod kojih je rađena citološka dijagnostika preživjelo je četiri godine u odnosu na $5 \%$ pacijenata u drugoj skupini u kojoj je rađena isključivo patohistološka dijagnostika ${ }^{11,13}$. Kod pacijenata dijagnosticiranih citološkom dijagnostikom kemoterapija je primijenjena ranije u odnosu na skupinu koja je dijagnosticirana isključivo patohistološkom dijagnostikom. Isključiva dijagnostika biopsijom bez kombiniranja s citologijom može odgoditi postavljanje dijagnoze do mjesec dana, što može umanjiti korisne učinke kemoterapije ${ }^{11}$. Citološkom analizom pleularnog izljeva moguće je dijagnosticirati maligni mezoteliom, a dijagnoza malignog mezotelioma temelji se na obilnoj celularnosti uzorka te citomorfološkim osobinama staničnih nakupina i tumorskih stanica uz obaveznu imunocitokemijsku analizu. Prema trenutnim smjernicama za citopatološku dijagnozu epiteloidnog i mješovitog tipa MM-a, uz nalaz malignih stanica karakteristične morfologije, potrebna su dva pozitivna imunocitokemijska markera koji potvrđuju te dva negativna markera koji isključuju mezotelno podrijetlo stanica ${ }^{11,14}$. Tumorske stanice mezotelnog porijekla pokazuju pozitivitet na markere kao što je kalretinin, keratin 5/6, mezotelin, HBME-1, podoplanin (D2-40) te WT-1, dok dijagnozu MM-a isključuju CEA, napsin $A$, Claudin 4, BerEp-4, MOC-31, CD-15, B72.3, TTF-1 te Pax $8^{11,13,14}$. Claudin-4 nema križnih reakcija s mezotelnim stanicama, stoga je prema Siddiqui i sur. 
najbolji marker za isključivanje dijagnoze $\mathrm{MM}-\mathrm{a}^{6}$. MOC-31 pokazuje križnu reakciju s mezotelnim stanicama, kao i BerEP4 te bi se trebao izbjegavati pri sumnji na metastatsku leziju pleure ${ }^{6}$. CEA, CD15 te B72.3 također mogu križno reagirati s mezotelnim stanicama, imaju nisku senzitivnost te se smatraju zastarjelim markerima ${ }^{6}$. Nasuprot tome, za određivanje pozitiviteta mezotelnih stanica dobrim se izborom smatraju kalretinin, citokeratin 5/6, WT-1 te D2-406 . Gotovo svi epiteloidni mezoteliomi boje se $s$ kalretininom, no potreban je oprez u slučaju negativnog markera zbog mogućnosti lažnog negativiteta ${ }^{6}$. Zbog toga što nijedan od ovih markera nije $100 \%$ specifičan na mezoteliom, preporuka je koristiti dva i više markera pri postavljanju dijagnoze. Imunocitokemija se može primjenjivati na sedimentima citospina i na staničnim blokovima ${ }^{14}$.

Stanice sarkomatoidnog mezotelioma ne nalaze se u pleuralnom izljevu, što znači da je citološka dijagnoza mezotelioma primjenjiva na epiteloidnom i mješovitom tipu mezotelioma ${ }^{6,15}$.

Među glavnim problemima u dijagnostici malignog mezotelioma pleure ostaje razlikovanje benigne hiperplazije pleure i malignog mezotelioma. Benigna hiperplazija pleure može imitirati maligni proces hipercelularnošću, brojnim mitozama i citološkom atipijom ${ }^{6,16}$. U patohistološkom preparatu pojava jasne invazije tkiva ključna je karakteristika malignog mezotelioma, a u prikazu invazije mogu pomoći markeri poput pancitokeratina i kalretinina. Churg i suradnici opisuju p53, desmin, EMA, IMP-3 i GLUT-1 kao korisne markere za distinkciju malignih i benignih lezija, no potreban je oprez $u$ individualnim slučajevima zbog visoke mogućnosti pogreške ${ }^{17,18}$. Korisnijim se smatra pronalazak homozigotne delecije p16 (CDKN2A) pomoću FISH (engl. Fluorescence in situ hybridization) analize te gubitak ekspresije BAP1 ili MTAP koji se pronalaze jedino u malignim mezoteliomima, a mogu se analizirati u citološkim i bioptičkim uzorcima te u staničnim blokovima ${ }^{17-22}$. Benigne lezije pokazuju jasnu nuklearnu ekspresiju BAP1 te citoplazmatsku i ponekad nuklearnu ekspresiju MTAP na imunohistokemiji ${ }^{6}$. Nuklearni gubitak BAP1 te citoplazmatski gubitak MTAP uvijek ukazuje na malignu bolest ${ }^{6}$. Pojedinačna senzitivnost ovih triju testova za mezoteliom pleure iznosi oko $60 \%$, zbog čega se preporučuje primjena barem dvaju testova u dijagnostici pojedinog slučaja, pri čemu senzitivnost raste na 80 do $90 \%{ }^{6}$. Navedeni se testovi trenutno ne koriste u rutinskoj dijagnostici, iako je moguće da će se početi koristiti u budućnosti ${ }^{15}$. Chapel i suradnici navode korisnom uporabu imunohistokemijskog panela koji uključuje dva mezotelna biljega (kalretinin, CK5/ 6, WT-1 ili D2-40) i dva epitelna biljega (MOC-31 i klaudin-4). Nakon što se utvrdi mezotelno porijeklo, studije specifične za malignost

Rana dijagnoza i rani početak terapije poboljšavaju prognozu oboljelih od malignog mezotelioma, stoga se patohistološka dijagnostika koja je bila zlatni standard desetljećima, pokušava nadopuniti citološkom dijagnostikom. Citološki uzorak izljeva, najčešćeg prvog znaka bolesti, vrlo je vrijedan rani dijagnostički, biološki materijal do kojeg se može doći na jednostavan način, pleuralnom punkcijom.

mogu pomoći u potvrđivanju dijagnoze malignog mezotelioma. Gubitak BAP1, homozigotna delecija CDCN2A i gubitak MTAP visoko su specifični biljezi malignosti u mezotelnoj leziji i postižu prihvatljivu dijagnostičku osjetljivost. Novi markeri malignosti, poput gubitka 5-hmC i povećane ekspresije EZH2 obećavaju, ali još uvijek nisu postigli široku kliničku primjenu. Neki dijagnostički biljezi također imaju prognostički značaj, a ekspresija PD-L1 može predvidjeti odgovor tumora na imunoterapiju².

\section{SERUMSKI BIOMARKERI}

Serumski biomarkeri razmatraju se kao skrining metoda u populaciji visokog rizika koja je prethodno bila izložena azbestu te se razmatra primjena u dijagnostici mezotelioma, određivanju prognoze bolesti i praćenju bolesti. Idealan biomarker bi trebao razlikovati maligni mezoteliom od zdravih kontrola već u ranom stadiju bolesti te ujedno benigne i maligne lezije $e^{4,9,24}$.

SM (engl. Soluble mesothelin) je glikoprotein kojeg eksprimira epiteloidna komponenta malignih mezotelnih stanica te se odlikuje visokom specifičnošću, ali niskom senzitivnošću kod dijagnostike $\mathrm{MM}-\mathrm{a}^{9,24,25}$. Osteopontin je pokazao nisku 
specifičnost u dijagnozi MM-a, dok su kod fibulina-3 rezultati neujednačeni. Primjena panela biomarkera mogla bi povećati specifičnost i senzitivnost $u$ odnosu na primjenu individualnih biomarkera ${ }^{9,24}$.

Primjena biomarkera u kliničkoj praksi za sada je ograničena zbog nedovoljne senzitivnosti i specifičnosti biomarkera ${ }^{15}$.

\section{ZAKLJUČAK}

Maligni mezoteliom pleure agresivna je bolest koja se najčešće otkriva u uznapredovalom stadiju kada su terapijske mogućnosti ograničene. Detekcija mezotelioma u ranijoj fazi bolesti povezana je s boljim preživljavanjem pacijenata, stoga je vrlo važan razvoj novih i manje invazivnih dijagnostičkih metoda koje će omogućiti otkrivanje bolesti u ranijem stadiju. Po trenutnim smjernicama, uz slikovne metode, morfološka tkivna analiza osnova je u postavljanju dijagnoze malignog mezotelioma pleure, a u novije vrijeme patohistološka se dijagnostika sve više nadopunjava citološkom analizom izljeva kao jednog od najranijih znakova bolesti. Uz primjenu imunocitokemijskih analiza, citologija izljeva predstavlja napredak u dijagnostici MM-a. Detekcija serumskih biomarkera razmatra se kao skrining metoda u populaciji visokog rizika koja je prethodno bila izložena azbestu, no njihova primjena u kliničkoj praksi za sada je ograničena zbog nedovoljne specifičnosti i senzitivnosti. Uzimajući u obzir da je uza sve navedene dijagnostičke metode smrtnost i dalje visoka, ukazuje se potreba za daljnjim istraživanjem, pronalaskom novih i unaprjeđenjem postojećih dijagnostičkih metoda.

Izjava o sukobu interesa: Autori izjavljuju kako ne postoji sukob interesa.

\section{LITERATURA}

1. Wagner JC, Sleggs CA, Marchand P. Diffuse Pleural Mesothelioma and Asbestos Exposure in the North Western Cape. Br J Ind Med 1960;17:260-71.

2. Alpert N, Gerwen M, Taioli E. Epidemiology of mesothelioma in the 21st century in Europe and the United States, 40 years after restricted/banned asbestos use. Transl Lung Cancer Res 2020;9:28-38.

3. Glodić G, Koprivanac A, Mažuranić A, Dujmović T, Marušić $A$, Pleština $S$, et al. Klinička obilježja i preživljenje bolesnika s malignim mezoteliomom pleure - iskustvo jednog centra. Liječ Vjesn 2020;142:306-14.
4. Kondola S, Manners D, Nowak AK. Malignant pleural mesothelioma: an update on diagnosis and treatment options. Ther Adv Respir Dis 2016;10:275-88.

5. Bibby AC, Tsim S, Kanellakis N, Ball H, Talbot DC, Blyth $K G$, et al. Malignant pleural mesothelioma: an update on investigation, diagnosis and treatment. Eur Respir Rev 2016;25:472-86.

6. Siddiqui MT, Schmitt F, Churg A. Proceedings of the American Society of Cytopathology companion session at the 2019 United States and Canadian Academy of Pathology Annual meeting, part 2: effusion cytology with focus on theranostics and diagnosis of malignant mesothelioma. J Am Soc Cytopathol 2019;8:352-61.

7. Sinha S, Swift AJ, Kamil MA, Matthews S, Bull MJ, Fisher $P$, et al. The role of imaging in malignant pleural mesothelioma: an update after the 2018 BTS guidelines. Clin Radiol 2020;75:423-32.

8. Gill RR, Tsao AS, Kindler HL, Richards WG, Armato SG, Francis RJ, et al. Radiologic Considerations and Standardization of Malignant Pleural Mesothelioma Imaging Within Clinical Trials: Consensus Statement from the $\mathrm{NCl}$ Thoracic Malignancy Steering Committee - International Association for the Study of Lung Cancer - Mesothelioma. J Thorac Oncol 2019;14:1718-31.

9. Arnold DT, Maskell NA. Biomarkers in mesothelioma. Ann Clin Biochem 2018;55:49-58.

10. Kim RY, Sterman DH, Haas AR. Malignant Mesothelioma: Has Anything Changed? Semin Respir Crit Care Med 2019;40:347-60.

11. Own SA, Höijer J, Hillerdahl G, Dobra K, Hjerpe A. Effusion cytology of malignant mesothelioma enables earlier diagnosis and recognizes patients with better prognosis. Diagn Cytopathol 2020;1:1-9.

12. Sheffield BS, Hwang HC, Lee AF, Thompson K, Rodriguez $\mathrm{S}$, Tse $\mathrm{CH}$, et al. BAP1 immunohistochemistry and p16 FISH to separate benign from malignant mesothelial proliferations. Am J Surg Pathol 2015;39:977-82.

13. Muruganandan S, Alfonso $H$, Franklin $P$, Shilkin $K$, Segal A, Olsen $\mathrm{N}$, et al. Comparison of outcomes following a cytological or histological diagnosis of malignant mesothelioma. Br J Cancer 2017;116:703-8.

14. Hjerpe A, Ascoli V, Bedrossian CW, Boon ME, Creaney J, Davidson B et al. Guidelines for the cytopathologic diagnosis of epithelioid and mixed-type malignant mesothelioma. Complementary statement from the International Mesothelioma Interest Group, also endorsed by the International Academy of Cytology and the Papanicolaou Society of Cytopathology. Acta Cytol 2015;59:2-16.

15. Katzman D, Sterman DH. Updates in the diagnosis and treatment of malignant pleural mesothelioma. Curr Opin Pulm Med 2018;24:319-26.

16. Husain AN, Colby TV, Ordóñez NG, Allen TC, Attanoos RL, Beasley MB et al. Guidelines for Pathologic Diagnosis of Malignant Mesothelioma 2017 Update of the Consensus Statement From the International Mesothelioma Interest Group. Arch Pathol Lab Med 2018;142:89-108.

17. Churg A, Sheffield BS, Galateau-Salle F. New Markers for Separating Benign From Malignant Mesothelial Proliferations: Are We There Yet?. Arch Pathol Lab Med 2016;140:318-21.

18. Hwang HC, Sheffield BS, Rodriguez S, Thompson K, Tse $\mathrm{CH}$, Gown AM et al. Utility of BAP1 Immunohistochemistry and p16 (CDKN2A) FISH in the Diagnosis of Malignant 
Mesothelioma in Effusion Cytology Specimens. Am J Surg Pathol 2016;40:120-6.

19. Hiroshima K, Wu D, Hasegawa M, Koh E, Sekine Y, Ozaki $D$ et al. Cytologic Differential Diagnosis of Malignant Mesothelioma and Reactive Mesothelial Cells With FISH Analysis of p16. Diagn Cytopathol 2016;44:591-8.

20. Önder S, Özogul E, Koksal D, Ulasli SS, Firat P, Emri S. Diagnostic value of BRCA1-associated protein-1, glucose transporter-1 and desmin expression in the discrimination between reactive mesothelial proliferation and malignant mesothelioma in tissues and effusions. Cytopathology 2019;30:592-600

21. Cigognetti $M$, Lonardi S, Fisogni $S$, Balzarini P, Pellegrini $\mathrm{V}$, Tironi A et al. BAP1 (BRCA1-associated protein 1) is a highly specific marker for differentiating mesothelioma from reactive mesothelial proliferations. Mod Pathol 2015;28:1043-57.
22. Kinoshita $\mathrm{Y}$, Hida $\mathrm{T}$, Hamasaki M, Matsumoto S, Sato A, Tsujimura T et al. A combination of MTAP and BAP1 immunohistochemistry in pleural effusion cytology for the diagnosis of mesothelioma. Cancer Cytopathol 2018; 126:54-63.

23. Chapel DB, Schulte JJ, Husain AN, Krausz T. Application of immunohistochemistry in diagnosis and management of malignant mesothelioma. Transl Lung Cancer Res 2020;9:3-27.

24. Gillezeau CN, Gerwen M, Ramos J, Liu B, Flores R, Taioli E. Biomarkers for malignant pleural mesothelioma: a meta-analysis. Carcinogenesis 2019;40:1320-31.

25. Cui A, Jin XG, Zhai K, Tong ZH, Shi HZ. Diagnostic values of soluble mesothelin-related peptides for malignant pleural mesothelioma: updated meta-analysis. BMJ Open [Internet]. 2014;4. [cited 2020 Sep 1]. Available from: https://bmjopen.bmj.com/content/4/2/e004145. 